\title{
MONOGRAFIE/MONOGRAPH
}

Valérie Tothová, Věra Hellerová (eds) (2021). Využití měřicích nástrojů v ošetřovatelství [Use of measuring instruments in nursing]. Praha. NLN, s. r. o. 225 s. ISBN 978-80-7422-817-9. DOI: 10.32725/zsf.2021.74228179

\section{Hodnocení bolesti u chirurgických pacientů}

kap. 6: DOI: 10.32725/zsf.2021.74228179.04

\section{Věra Hellerová}

University of South Bohemia in České Budějovice, Faculty of Health and Social Sciences, Institute of Nursing, Midwifery and Emergency Care, České Budějovice, Czech Republic

\section{Souhrn}

Hodnocení bolesti stejně jako účinku intervencí směřujících $k$ jejímu snížení patří $k$ základním dovednostem každé sestry. Z podstaty zaměření chirurgických oborů je jasné, že $v$ tomto prípadě má hodnocení svá specifika. Současné ošetřovatelství, vědecko-technický pokrok, multimédia nám poskytují řadu podnětů a inspiraci, jak management bolesti zkvalitnit. Pro EBN a zejména EBP je schopnost učit se novým věcem a určitá otevřenost nezbytná. Sestry mají k dispozici řadu standardizovaných nástrojů pro hodnocení bolesti, které jsou objektivní, efektivní, validní. Míra jejich využití sice záleží na daném zdravotnickém zařízení, ale je také v rukou sester samotných. Ukazuje se, že kvalita péče poskytované v rámci managementu bolesti ve smyslu hodnocení bolesti, využívání kritického myšlení v průběhu tohoto procesu, navázání spolupráce s pacientem i lékařem, je ovlivněná řadou faktorů. Nelze přitom opomenout roli délky praxe a vzdělání sester. Kromě vhledu do současného stavu hodnocení bolesti u chirurgických pacientů v Jihočeském kraji naše výsledky přinášejí inspiraci k využití standardizovaného nástroje SF-MPQ-2. Ten může sestrám pomoci v posouzení fyzické a emoční složky bolesti, což je pro celkovou léčbu bolesti důležité.

Klíčová slova: hodnocení bolesti, chirurgický pacient, praxe sester, standardizovaný nástroj, vzdělání sester

\section{Podkapitoly:}

6.1 Bolest jako ošetřovatelská diagnóza

6.2 Škály využívané pro hodnocení bolesti

\section{Literatura}

1. Buppha, P., et al. (2016). Reliability and Validity of the Thai Short-Form McGill Pain Questionnaire-2 (SFMPQ-2). J Anesth Clin Res 7: 651. DOI: 10.4172/2155-6148.1000650.

2. Campagna, S., et al. (2016). Postoperative pain, an unmet problem in day or overnight Italian surgery patients: a prospective study. Pain Res Manag 2016: 6104383. DOI: 10.1155/2016/6104383.

3. Corbett, A., et al. (2014). The importance of pain management in older people with dementia. Br Med Bull 111 (1): 139-148. DOI: 10.1093/bmb/ldu023.

4. Daneš, L. (2018). Bolest a sexuální dysfunkce mužů. Praha: Grada, 152 s. 
5. Dworkin, R. H., et al. (2009). Development and initial validation of an expanded and revised vision of the Short-form McGill Pain Questionnaire (SF-MPQ-2). Pain 144(1-2): 35-42. DOI:

10.1016/j.pain.2009.02.007.

6. Edirisinghe, N. P., et al. (2019). Psychometric properties of Sinhala version of short-form McGill pain questionnaire-2 (sf mpq-2-sin) among patients with cancer pain in Sri Lanka. Pain Res Manag 2019: 5050979. DOI: 10.1155/2019/5050979.

7. Fernandez, E. (2005). The relationship between anger and pain. Curr Pain Headache Rep 9(2): 101-105. DOI: 10.1007/s11916-005-0046-z.

8. Göransoon, K. E., et al. (2015). Pain rating in the ED - a comparison between 2 scales in a Swedish hospital. Am J Emerg Med 33(3): 419-422. DOI: 10.1016/j.ajem.2014.12.069.

9. Gregory, J. (2019). Use of pain scales and observational pain assessment tools in hospital settings. Nurs Stand (v tisku). DOI: 10.7748/ns.2019.e11308.

10. Hasvik, E., et al. (2019). Cross-cultural adaptation and validation of the Norwegian short-form McGill pain questionnaire-2 in low back-related leg pain. Spine 44(13): E774-E781. DOI: 10.1097/BRS.0000000000002976.

11. Herr, K. (2011). Pain assessment strategies in older patients. J Pain 12(3 Suppl. 1): S3-S13. DOI: 10.1016/j.jpain.2010.11.011.

12. Hřib, R., Hakl, M. (2005). Akutní bolest. Remedia. [online] [cit. 2020-01-22]. Dostupné z: http://www.remedia.cz/Archiv-rocniku/Rocnik-2005/4-5-2005/Akutni-bolest/e-9n-9MaX.magarticle.aspx

13. Chromý, P., Honzák, R., a kol. (2005). Somatizace a funkční poruchy. Praha: Grada.

14. IASP (2017). IASP Terminology. [online] [cit. 2020-01-22]. Dostupné z: https://www.iasppain.org/Education/Content.aspx?ItemNumber=1698

15. IASP (2019). IASP's Proposed New Definition of Pain Released for Comment. [online] [cit. 2020-01-22]. Dostupné z: https://www.iasp-pain.org/PublicationsNews/NewsDetail.aspx?ltemNumber=9218

16. Jorns, T. P., et al. (2019). Validity and reliability testing of the e-san version of the short-form McGill pain questionnaire in musculoskeletal, neuropathic and odontogenic pain. J Med Assoc Thai 102(4): 75-81.

17. Karlsten, R., et al. (2005). Improving assessment of postoperative pain in surgical wards by education and training. Qual Saf Health Care 14(5): 332-335. DOI: 10.1136/qshc.2004.010330.

18. Kiavar, M., et al. (2016). Comparison of Two Pain Assessment Tools, "Facial Expression" and "Critical Care Pain Observation Tool" in Intubated Patients After Cardiac Surgery. Anesth Pain Med 6(1): e33434. DOI: 10.5812/aapm.33434.

19. Knotek, P., et al. (2002). Czech version of the short form of the McGill University pain questionnaire: restandardization. Bolest 5(3): 169-172.

20. Kolektiv autorů (2006). Vše o léčbě bolesti: př́ručka pro sestry. Praha: Grada, 355 s.

21. Koutná, M., et al. (2017). Validizace ošetřovatelské diagnózy akutní a chronická bolest dle NANDA International u pacientů s ránou. Cesk Slov Neurol N 80(Suppl. 1): 54-60. DOI: 10.14735/amcsnn2017S54.

22. Křivohlavý, J. (1992). Bolest - její diagnostika a psychoterapie. Brno: Institut pro další vzdělávání pracovníků ve zdravotnictví, $66 \mathrm{~s}$.

23. Kumar, K. H., Elavarasi, P. (2016). Definition of pain and classification of pain disorders. J Adv Clin Res Insights 3: 87-90. DOI: 10.15713/ins.jcri.112.

24. Málek, J., Ševčík, P., a kol. (2014). Léčba pooperační bolesti. Praha: Mladá fronta, $152 \mathrm{~s}$.

25. Mandysová, P., et al. (2017). Comparison of Three Self- Report Pain Scales in Czech Patients with Stroke. Central Eropean Journal of Nursing and Midwifery 8(1): 572-579. DOI: 10.15452/CEJNM.2017.08.0004.

26. Meissner, W., Zaslansky, R. (2019). A survey of postoperative pain treatments and unmet needs. Best Pract Res Clin Anaesthesiol 33(3): 269-286. DOI: 10.1016/j.bpa.2019.10.003.

27. Melzack, R. (1987). The short-form McGill Pain Questionnaire. Pain 30(2): 191-197. DOI: 10.1016/03043959(87)91074-8. 
28. Ministerstvo zdravotnictví České republiky (2020). Národní ošetřovatelský postup. Péče o pacienta s bolestí. [online] [cit. 2020-01-22]. Dostupné z: https://www.mzcr.cz/wpcontent/uploads/wepub/18576/40361/NOP\%20P\%C3\%A9\%C4\%8De\%20o\%20pacienta\%20s\%20bolest\% C3\%AD.pdf

29. Mustajoki, M., et al. (2020). Pain assessment in native and non-native language: Difficulties in reporting the affective dimensions of pain. Scand J Pain 18(4): 575-580. DOI: 10.1515/sjpain-2018-0043.

30. NANDA International (2020). Ošetřovatelské diagnózy. Definice a klasifikace. 2018-2020. 11. vyd. Praha: Grada.

31. Okifuji, A., et al. (1999). Anger in chronic pain: investigations of anger targets and intensity. J Psychosom Res 47(1): 1-12. DOI: 10.1016/s0022-3999(99)00006-9.

32. Olišarová, V., et al. (2020). Pain assessment in surgical patients in the South Bohemia Region. Cent Eur J Nurs Midw 11(2): 62-69. DOI: 10.15452/CEJNM.2020.11.0011.

33. Olisarova, V., et al. (2021). Pain Assessment: Benefits of Using Pain Scales for Surgical Patients in South Bohemian Hospitals. Healthcare (Basel) 9(2): 171. DOI: 10.3390/healthcare9020171.

34. Pavlin, D. J., et al. (2004). A survey of pain and other symptoms that affect the recovery process after discharge from an ambulatory surgery unit. J Clin Anesth 16(3): 200-206. DOI: 10.1016/j.jclinane.2003.08.004.

35. Pinto, A., et al. (2016). Surgical complications and their impact on patients' psychosocial well-being: a systematic review and meta-analysis. BMJ Open 6(2): e007224. DOI: 10.1136/bmjopen-2014-007224.

36. Pokorná, A., a kol. (2013). Ošetřovatelství v geriatrii. Praha: Grada, 202 s.

37. Sinatra, R. (2010). Causes and Consequences of Inadequate Management of Acute Pain. Pain Med 11(12): 1859-1871. DOI: 10.1111/j.1526-4637.2010.00983.x.

38. Rokyta, R., a kol. (2009). Bolest a jak s ní zacházet. Praha: Grada.

39. Rokyta, R., Kršiak, M., Kozák, J. (2012). Bolest. 2., přeprac. vyd. Praha: Tigis.

40. Rosén, H. I., et al. (2011). Patients' experiences of pain following day surgery - at 48 hours, seven days and three months. Open Nurs J 5: 52-59. DOI: 10.2174/1874434601105010052.

41. Sinatra, R. (2010). Causes and Consequences of Inadequate Management of Acute Pain. Pain Med 11(12): 1859-1871. DOI: 10.1111/j.1526-4637.2010.00983.x.

42. Snow, A. L., et al. (2004). Conceptual Model of Pain Assessment for Noncommunicative Persons With Dementia. Gerontologist 44(6): 807-817. DOI: 10.1093/geront/44.6.807.

43. Swift, A. W. (2018) Understanding pain and the human body's response to it. Nursing Times 114(3): 2226.

44. Vorlíček, J., Abrahámová, J., Vorličková, H., a kol. (2012). Klinická onkologie pro sestry. 2., přeprac. a doplněné vyd. Praha: Grada, $448 \mathrm{~s}$.

45. Zacharová, E., Haluzíková, J. (2013). Bolest a její zvládání v ošetřovatelské péči. Interní Med 15(11-12): 372-374. 